\title{
Analysis on Development Problems of Private Colleges Educational Foundation
}

\author{
Shuaihong Wang ${ }^{1, a}$ \\ ${ }^{1}$ Xi'an International University, Xi'an, Shaanxi, 710077 \\ a email,
}

Keywords: Private Colleges, Educational Foundation, Education

\begin{abstract}
In this paper, the current development situation of private higher education foundation with its own characteristics are the starting point of the article, in order to develop private education foundation universities into important reality, to indicate that private education foundation for the overall education of colleges and universities living with people effectively played important. Thus standing the specific problems of Education Foundation of Private Colleges exist and cause problems are expanded to discuss, analysis on the Education Foundation's "short board" from a more detailed view, in order to further raise the private funding of higher education specific development proposal will, the purpose is to promote private education foundation to achieve sustainable development in colleges and universities on more scientific, standardized and humane standards, and fully play a key role in Private Education Foundation Private Universities in many strategic development Universities and positive impact.
\end{abstract}

\section{Introduction}

Widely established on the Education Foundation, they exist for the development of many colleges and universities to create a good space for development and the environment, and give great help college financial support from the point of view. But the development so far, due to the combined effect of a variety of domestic factors, such as the popularity of the concept of domestic charity range is not wide, relatively weak political and legal support, various colleges and universities of their own subjective status is not clear and other factors that have made private education Colleges Foundation own existence founder enthusiasm is not high, the overall number of funds and set up a small-scale problems. And these problems led directly to the development of private higher education foundation hampered and influence, is not conducive to efficient private education Colleges Foundation, scientific and all the people of the development goals. Based on this, standing on the perspective of Private University Education Foundation to discuss their specific development proposals, thus promoting the development of private higher education Foundation more fit the current development situation of education.

\section{First, on the Education Foundation for Development Overview and Features}

As early as the sixteenth century, the British and many educators have proposed the need for educational foundation established, and there have been relevant organizations similar educational foundations. From Educational Foundation in our country's development process point of view, is a self-1990s, China's Private Colleges Education Foundation as a nonprofit organization, its development and the establishment of the number of rapid growth, and gradually formed part own development system. At present, the Education Foundation of Private Colleges mainly includes the following development model, that type of administration, the Commission based, market operation type and overseas expansion type, etc. [1].

Although the reform and opening up China's education has also been a good opportunity for development, but compared with Western developed countries, there are still some development gaps. Development Status of Private Colleges Education Fund's performance is currently out of the following features:

First, attach great importance to the important role of Private Colleges Private Colleges 
Education Foundation, so that the number of more and more Education Foundation founder, set up speed gradually accelerated; second, China Education Foundation Private University has formed a variety of coexistence model development system, but in a single mode of operation is still more money; third, private education is largely College Foundation provides a good impetus for their own development of private universities, and deep financial support; fourth, Private Education foundation Colleges and Universities Alumni inside the close contacts played a guiding role in the Alumni Association's daily work and activities carried out in and lay a good foundation for basic Alumni work; a fifth from private higher education Foundation Gets composition of capital, the formation of capital in the case of education fund earmarked accounts never more, its multi-class infrastructure for the development of the donation and the donation form.

From a practical point of view of the construction of the foundation of private higher education point of view, it also has the following characteristics: First, the Education Foundation is to address the shortage of domestic funds Private Colleges important role; secondly, classified management system of domestic private colleges is Education Foundation the fundamental guarantee for construction; again, the flow of private capital is abundant source of funding private University Education Foundation; and finally, society hoist private Colleges Foundation Social Credit has become more perfect [2].

\section{China Education Foundation Private Colleges Problems and Causes}

Current Issues of the Educational Foundation of Private Universities. First, the size of funds on the Education Foundation's relatively small share of total income donated funds and universities the proportion to be further improved. In the current domestic private colleges and universities have established Universities Private Education Foundation, the Foundation for a larger number of public universities in the transfer of the money, almost all exceeded one billion mark. However, the number of internal funds raised on the Education Foundation has a lot of difference, and the funds are relatively small, there is no good foundation for large-scale fund-raising.

Second, on the Education Foundation's management model based mostly administrative type can not be very comprehensive to meet the current needs of the market economy. Since the administrative type Educational Foundation under management, the management usually has way too stiff, weak management, and funding channels for a single, low fund-raising initiative, and work efficiency is too low and other shortcomings. The presence of these shortcomings can not provide a good impetus and support for the development of private higher education foundation and it is not conducive to a good education foundation breakthrough in the size of funds.

The internal mechanism of operation has the Fund of Private Education Foundation Colleges unsound, leading to low profitability of funds. Many private colleges and universities is not very great importance to the presence of Education Foundation, and Private Education Foundation universities have ignored their own ways and methods of operation of the Fund. Well, from the perspective of the collection of funds and fund sources speaking, since the foundation of their own lack of good diversity in the operating mechanism, unable to carry out additional sources of funds, resulting in lower investment on the Education Foundation, the Foundation can not expanded power to make support [3].

Fourth, on the Education Foundation's organization are not perfect and lack of full-time staff with intensity. Education Foundation is an important internal organization of private universities, which should have a complete organizational management framework and corresponding staff. But many domestic private colleges and universities in the organization set up on the Education Foundation is too perfunctory, hastily set up in the various agencies and departments in full-time, with personnel and is not in full-time professional management and operation of the Foundation talent, seriously affecting the efficiency and intensity of work on the Education Foundation, but also greatly reduces the play of Private educational Foundation of Universities functions.

Problems in Private College Education Foundation Analysis. First, the lack of public welfare in most private colleges and universities, the fine cultural traditions of philanthropy, leading founder of the Foundation's work is not very scientific; secondly, domestic and Education 
Foundation-related laws and policies need to be further improved, so that the current policy limitations of the legal environment, the impact of many good play on the Education Foundation functions; and finally, private colleges own subjective position is not clear, and the Private Education Foundation of Universities and founder of Xing constructive and positive level is not high, good development Foundation negative impact [4].

\section{Promote the Development of Private Education Foundations Colleges Good Advice}

Gradual Optimization of Private Education Foundation in Colleges External Environment. First of all, our government should actively recommend the introduction of tax policy on "intellectual property" related, such as inheritance tax, resource tax, so as to mobilize the attention of many social roles and levels of participation in education at all. Through good survey of Current Private Colleges funding approval process, effectively creating a Private Education Foundation Colleges favorable policy environment, promote the sound development; secondly, to guide the government and private colleges and universities build between good and harmonious relationship between the body, so that in under the protection of government to achieve healthy development of private colleges and universities, but also provide a good guarantee for scientific policy of Private Higher Education Foundation; and finally, to a large current efforts to improve the use of university evaluation system and assessment mechanism, and drawing on the use of the United States "ability to receive a" mechanism to effectively guide the sound development of private education in Colleges Foundation balanced budget, high efficiency mechanism condition financing capacity.

Strengthen the Internal Education Foundation of Private Universities. First, the private education foundations Colleges should be reasonable to choose their own development and in accordance with the laws of market economy management model, not only to match the aspect of operating a school tradition, the interior department of the organization and so on, but also in accordance with market economy can their conditions are selected to produce the optimal funding schemes, highlighting the role of economic levers; secondly, to improve the position of Private Colleges and Education Foundation in position inside of Private Colleges and Universities to enhance the importance of the construction of the foundation, and is equipped with high-quality, specialized personnel. For example, in the establishment of the Education Foundation of Harvard University, a total of a hundred and fifty highly qualified full-time staff to operate and manage the internal affairs of the Foundation for the Development of University itself plays an important basic strength; Third, we must fully using various channels and means to expand the sources of funding and scope of the Private University Education Foundation raised funds, greatly increase the number of sources of funding. Raised funds and non-public fund can be set up to improve the sources of funding for education from the perspective of a more diversified; Finally, to work to strengthen the system of Private Education Foundation Colleges use of power from the system to boot on the Education Fund good development will. By increasing the transparency of social fund-raising, the establishment of the relevant special fund-raising mechanism is to protect the Private University Education Foundation fundraising normative and strongly correct more social forces and social support [5].

Private Education Foundation to Establish and Improve the Supervision System Applicable Colleges. In order to fundamentally eliminate and prevent the presence of Private Colleges and Universities Education Foundation "black-box operation" phenomenon in the process of collecting funds, by vigorously improve and perfect the Private Education Foundation Colleges applicable financial supervision system, to protect the integrity of education funds. Based on this, the private education Colleges Foundation can take "three-tier" system of supervision and oversight body formed three foundations to internal oversight, supervision and Industry Education Foundation will be supervised injection to fully protect the private information within the College Education Foundation accuracy, fairness, from a reasonable degree of disclosure of information to judge and evaluate the normative Education Foundation, which play an effective system of regulation and control of the utility. 


\section{Conclusion}

In conclusion, private education colleges create a good space for development and the environment foundation for the development of many domestic private colleges and universities and give college great support from the financial point of view. Therefore, this paper points out problems of private education foundation universities and causes the underlying reasons for the existence of the problem, to analyze on the education foundation's "short board" from a more detailed view and further proposed private university education foundation specific development proposals and has future development routes for private education colleges development. In this paper, it is possible to know the future development planning and we should make full use of the system, power management and the external environment to effectively promote the healthy development of private higher education foundations, in order to make private colleges and universities to achieve the green, stabilization development.

\section{References}

[1] Shi Wenmei, Zhou Haitao. implementation of local innovation and developing private practice and Autonomy for Universities - Based on Analysis of Private Higher Education Policy in six provinces [J] Educational Development, 2014, Z1: 86-91.

[2] Guo Jianru, Ma Linxia. China's educational development vocational development orientation of Private Colleges and Policy Analysis - From the Perspective of International Comparison of Higher Education and the Private University Relations [J]. Private Education Research, 2015,01: + 36-45 107.

[3] Zhou Haitao, Liu Xia. Private Education Development Research Report - Based on nearly a decade of private colleges and universities nationwide statistics and policy text [J]. Chinese higher education, 2016,02: 18-22.

[4] Ji Jingjing. Season Situation of Higher Education Foundations and Development Path-A Case Study of Educational Foundation of Jiangsu Normal University [J]. Science and Technology Tribune, 2016, 13: 148.

[5] Huang Xiaoling. Private College Education Foundation, a non-profit development to protect Private Colleges - Based on the Management of Private Colleges classification [J]. Knowledge economy, 2015,14: $7+16$. 